\title{
Granulocyte Colony-Stimulating Factor (G-CSF) Induced Aortitis: A Case Report with Literature Review
}

\author{
Hye-Won Lee, Hong II Ha \\ Department of Radiology, Hallym University Sacred Heart Hospital, Anyang-si, Korea
}

Granulocyte colony-stimulating factor (G-CSF) is widely used as a neutrophil supportive therapy in cancer chemotherapy. Recently, some cases of G-CSF-induced aortitis are reported. Our case patient is a 54-yearold female diagnosed with breast cancer and received adjuvant chemotherapy with prophylactic use of G-CSF. She developed G-CSF-induced aortitis 20 days after the use of G-CSF. The disease was diagnosed with serum markers and radiologic findings. Her symptoms and imaging findings were rapidly improved with high-dose steroid therapy. The rapid improvement of the disease implies that prompt diagnosis with treatment can prevent severe vascular complications.

Keywords: Aortitis; Granulocyte colony-stimulating factor; Computed tomography

\section{Introduction}

Granulocyte colony-stimulating factor (G-CSF) is a kind of cytokine that belongs to the hematopoietin family. It regulates the leukocyte growth and maturation in the bone marrow (1). The common cytotoxic agents decrease the production of progenitor cells of the marrow. If the nadir neutrophil count is under 500/uL, the risk of death is markedly increased. G-CSF is broadly used to augment bone marrow production of polymorphonuclear leukocytes and reverse chemotherapeutic agent-induced neutropenia (2). However, recently, some cases have reported G-CSFinduced large vessel vasculitis. It is an infrequent adverse effect of G-CSF, and there are few reviews on published articles. We report a case of G-CSF-induced aortitis in a patient who was on adjuvant chemotherapy for breast cancer, and we thoroughly review this disease entity with published articles and our case.

\section{Case Report}

A 54-year-old female, who had been diagnosed with breast cancer, visited the emergency department eleven days after her first adjuvant chemotherapy cycle with doxorubicin and cyclophosphamide. She complains of a fever, and an emergent laboratory exam shows severe neutropenia (absolute neutrophil count: 96/uL). A longacting glycosylated G-CSF (lenograstim) was initiated with intravenous (IV) antibiotics (tazobactam) to revise the neutropenia. After two days, her fever was subsided, the

\footnotetext{
Received: June 15, 2021 Revised: June 23, 2021 Accepted: June 23, 2021 Correspondence: Hong II Ha, MD, PhD

Department of Radiology, Hallym University Sacred Heart Hospital, 22, Gwanpyeong-ro 170beon-gil, Dongan-gu, Anyang-si, Gyeonggi-do 14068 , Korea

Tel: +82-31-380-3880 E-mail: ha.hongil@gmail.com

This is an Open Access article distributed under the terms of the Creative Commons Attribution Non-Commercial License (http:// creativecommons.org/licenses/by-nc/4.0/) which permits unrestricted non-commercial use, distribution, and reproduction in any medium, provided the original work is properly cited.
} 
neutrophil count was increased, and C-reactive protein (CRP) was slightly decreased $(66.16 \mathrm{mg} / \mathrm{dL})$. After then, she has discharged.

However, she visited the emergency department four days after discharge for abdominal and back pain. On laboratory exam, an elevated CRP level $(98.02 \mathrm{mg} / \mathrm{dL}$ ) was noted. She underwent abdomen-pelvis computed tomography (CT) for evaluation. Previously, she took baseline abdomen-pelvis $\mathrm{CT}, 43$ days before the onset of symptom, and there was no remarkable finding (Fig. 1A). However, A newly developed soft-tissue density lesion encases the abdominal aorta with mild enhancement (Fig. 1B) at this time. The lesion was extended from the diaphragmatic crura to the bilateral renal vein level. It was suspected of aortitis, but the possible malignancy could not be excluded. She underwent ${ }^{18} \mathrm{~F}$-fluorodeoxyglucose positron emission tomography-computed tomography $\left({ }^{18} \mathrm{~F}-\mathrm{FDG}-\mathrm{PET} / \mathrm{CT}\right)$ for further evaluation. It revealed a thickening of the suprarenal abdominal aorta wall with strong FDG uptake (Fig. 2A, 2B) without other abnormality. When considering the medical history and radiologic findings, abdominal aortitis induced by G-CSF was strongly suspected. Serum rheumatoid factor and fluorescent antinuclear antibody tests were negative.

The treatment with intravenous steroids was immediately initiated the following day after diagnosis. The CRP levels

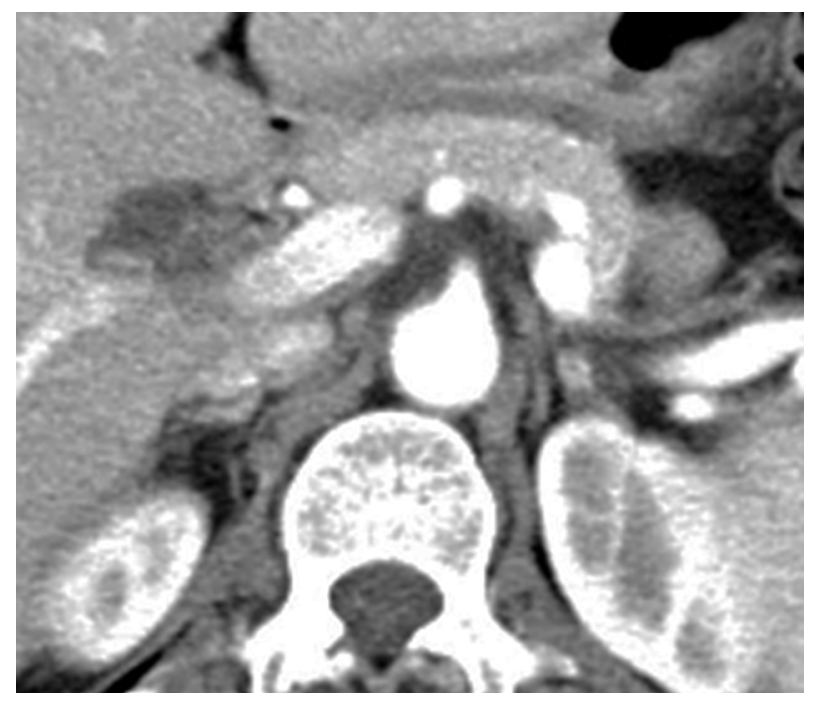

A

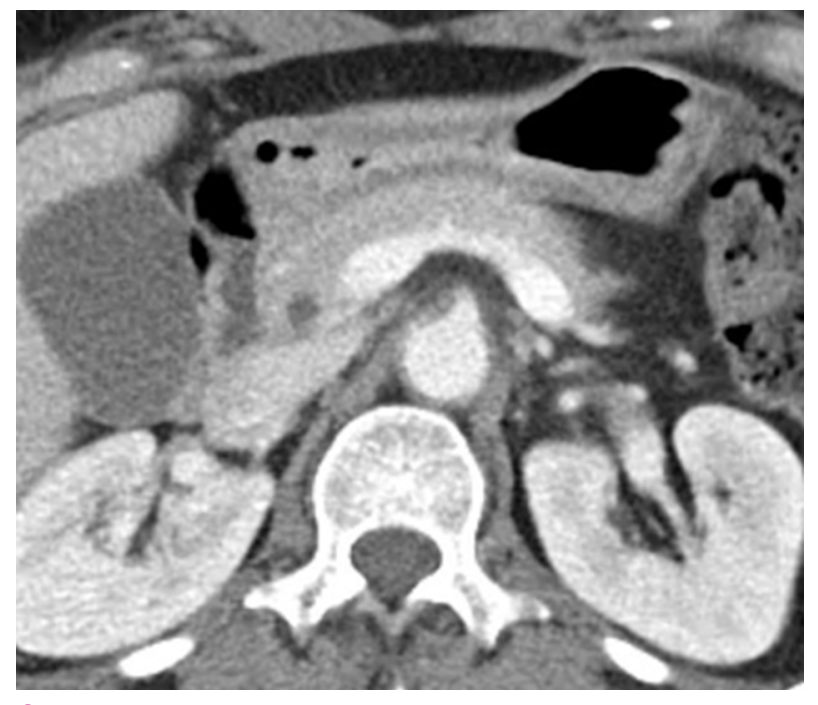

C

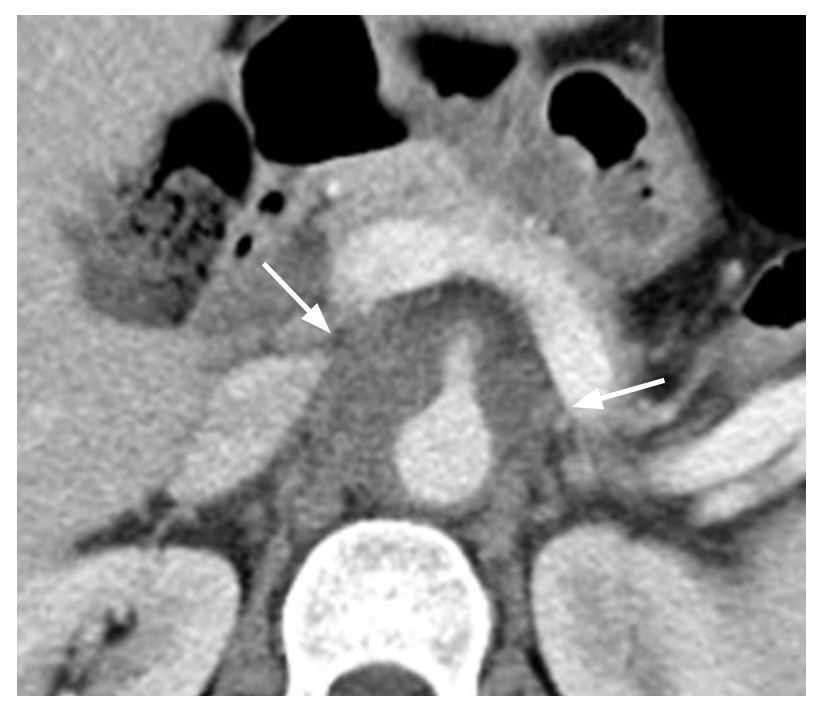

B

Fig. 1. (A) Baseline abdomen-pelvis CT reveals normal abdominal aorta without any inflammatory condition. (B) After the onset of the symptom, initial abdomen-pelvis $\mathrm{CT}$ reveals newly developed diffuse soft tissue density encasing suprarenal abdominal aorta (arrows). (C) On the second follow-up abdomen-pelvis $\mathrm{CT}$, aortitis is improved without any significant sequelae or complication. 
decreased rapidly, and the patient was discharged a few days later, following a rapid clinical improvement. After the high-dose steroid therapy, the dose tapering followed. A follow-up abdomen-pelvis CT scan was conducted 18 days after the second admission, and a second follow-up abdomen-pelvis CT scan 16 days after the first follow-up CT show improved aortitis with residual granulation tissue (Fig. 1C). Follow-up ${ }^{18} \mathrm{~F}$-FDG-PET/CT shows normalized metabolism in the involved area (Fig. 2C, 2D). The entire disease course is summarized in Figure 3.

The patient restarted the chemotherapy cycle without prophylactic G-CSF, and there was no recurrence of aortitis and no development of any associated complications.

\section{Discussion}

There are few reported cases with G-CSF-induced aortitis. When reviewed for previously published articles,

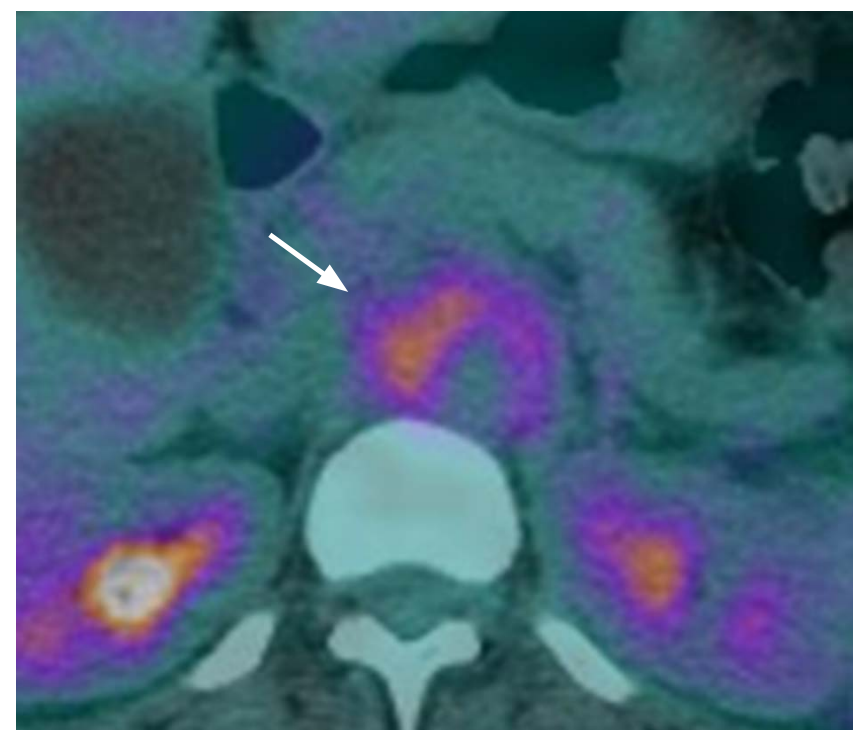

A

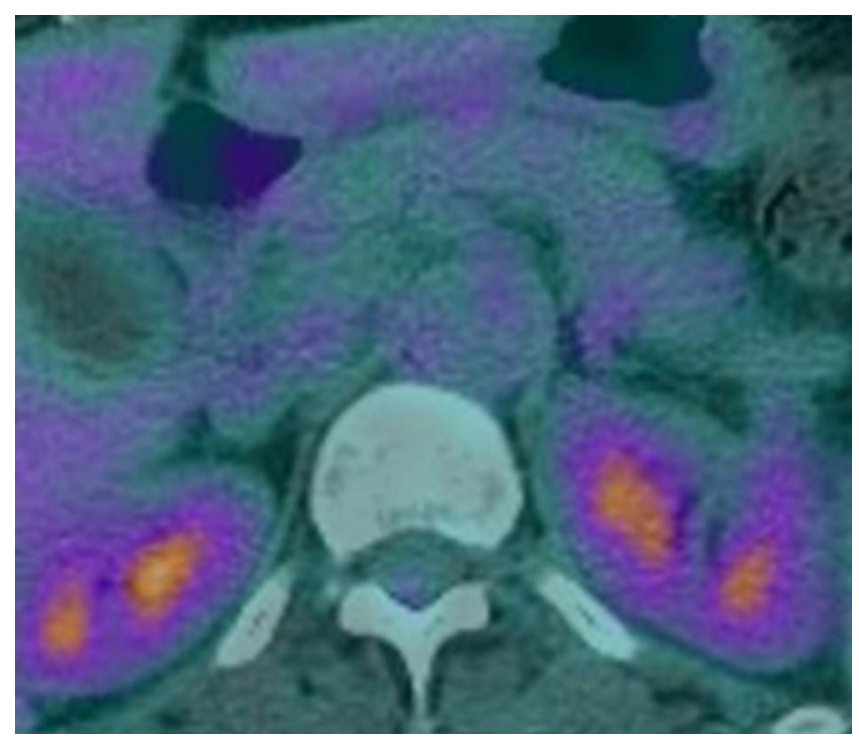

C

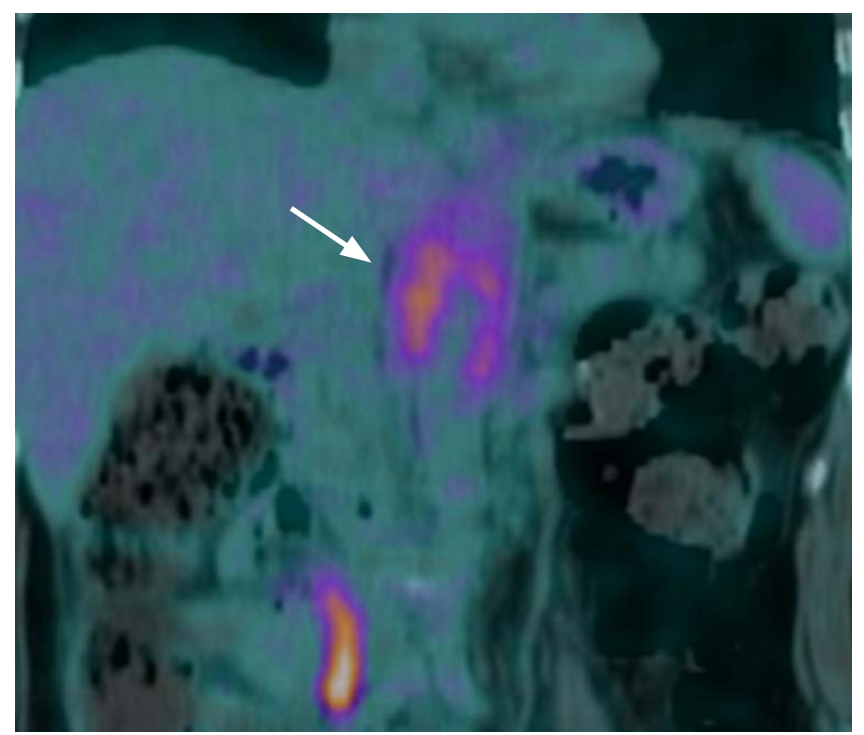

B

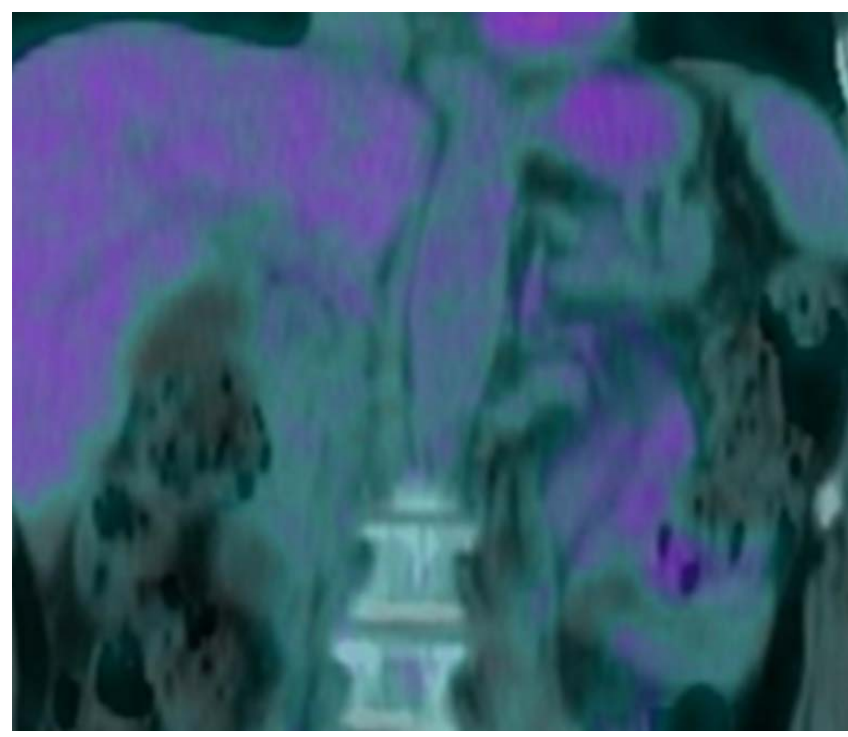

D

Fig. 2. Disease manifestation on PET/CT. (A), (B) Initial ${ }^{18} \mathrm{~F}$-FDG-PET/CT reveals increased metabolism around the abdominal aorta (arrows). (C), (D) Follow-up ${ }^{18} \mathrm{~F}-\mathrm{FDG}-\mathrm{PET} / \mathrm{CT}$ after steroid therapy reveals improvement of aortitis. 
except for one male case, most of the patients are women diagnosed with breast cancer who had been initiated chemotherapy with prophylactic G-CSF therapy. Two of the cases are remarkable because they did not have any underlying disease $(3,4)$. It suggests that some cases of aortitis seem to be caused by the G-CSF use rather than the chemotherapy agent.

Our case patient was diagnosed based on the symptom, medical history, serum markers, and radiologic findings, including abdominal CT and PET-CT. Similarly, reported cases were diagnosed by imaging modalities such as CT, magnetic resonance imaging (MRI), ultrasonography, and PET-CT. The most frequently used diagnostic tool was CT and PET-CT. CT may demonstrate thickening of the aortic wall and periaortic inflammation, although milder degrees of inflammation or wall edema may not be apparent (5). $\mathrm{CT}$ is used in the long-term follow-up of patients with treated aortitis, particularly for monitoring the progression of aortic aneurysm. MR angiography also can depict an area of active aortitis that appears as vessel wall edema, enhancement, or wall thickening (6). Recently, the use of ${ }^{18} \mathrm{~F}$-FDG-PET/CT has emerged as a potential tool for the initial diagnosis and assessment of disease activity of aortitis (7). Serum markers, including CRP and erythrocyte sedimentation rate, are easy ways to follow up and determine the endpoint of steroid therapy. Most reported patients have initiated G-CSF agents such as filgrastim or pegylated-filgrastim, but our case patient used G-CSF, which is the first reported case for this agent.

In a large vessel vasculitis, there are many reported complications such as aneurysm, stenosis, dissection, and even rupture (8). Some reported G-CSF-induced vasculitis cases revealed aortic dissection (9), iliac artery aneurysms (4), and left pleural effusion (10). It is recommended for suspected G-CSF-induced aortitis patients to undergo follow-up contrast-enhanced CT to evaluate the subacute or late complications.

G-CSF-induced aortitis is usually resolved spontaneously. However, a case shows long-term involvement of the G-CSF-induced aortitis (4). There is a possibility of developing severe complications like in other large vessel vasculitides (8). Thus, prompt diagnosis and rapid initiation of steroid therapy are essential for G-CSF-induced aortitis. Our case patient was treated based on this regimen

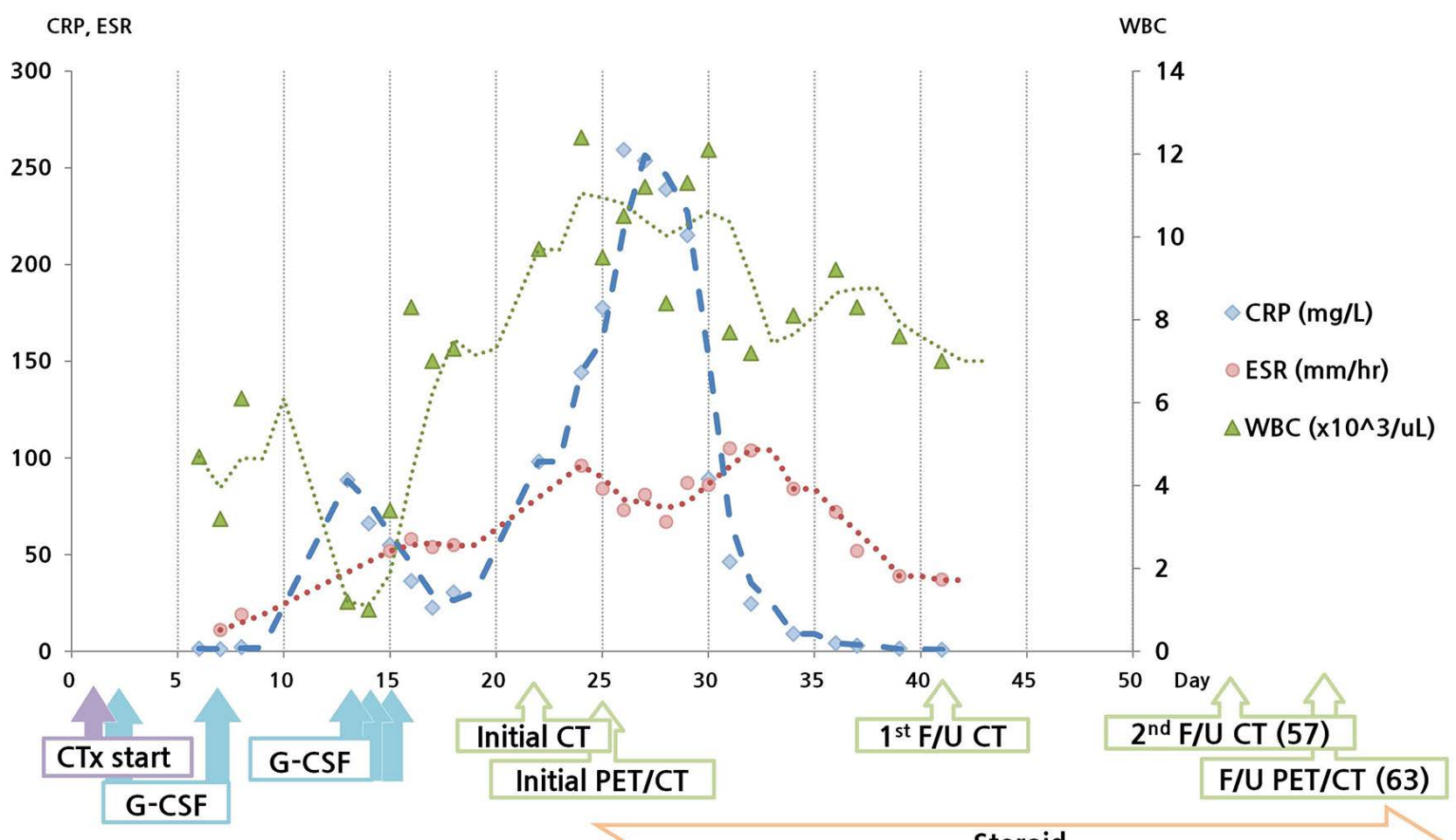

Steroid

Fig. 3. The schematic visualization of the case patient's disease course. 
$(11,12)$ : IV methylprednisolone $500 \mathrm{mg} /$ day for three days, followed by oral prednisolone at $1 \mathrm{mg} / \mathrm{kg}$ per day with dose tapering. This regimen was effective, and the patient's serum markers were completely normalized in a week after the initiation of the therapy.

\section{Conclusion}

We herein report a case of G-CSF-induced aortitis. This adverse event is scarcely reported, but the concept of G-CSF-induced aortitis is recently emerging. Because it seems to appear any patient who has undergone G-CSF therapy, it should be considered in cases of unexplained fever and no treatment response with antibiotics in case of receiving G-CSF therapy. High-dose steroid therapy seems to shorten the disease-affected period in several reported cases. We suggest that the treatment should be started promptly upon diagnosis. Andcontrast-enhanced CT is recommended for long-term follow-up of patients with treated aortitis, particularly for monitoring the subacute or late complications.

\section{Disclosure statement}

The authors report no conflict of interest.

\section{Authors' contributions}

Hye-Won Lee: wrote the paper

Hongil Ha: paper's conception, reviewed the paper, and approved the final version of the article

ORCID: Hye-Won Lee: https://orcid.org/0000-0002-6166-2468; Hong II Ha: https:// orcid.org/000-0001-9050-7486

\section{References}

1. Holland SM, Gallin JI. Disorders of Granulocytes and Monocytes. In: Jameson JL, Fauci AS, Kasper DL, Hauser SL, Longo DL, Loscalzo J, editors. Harrison's Principles of Internal Medicine, 20e. New York, NY: McGraw-Hill Education; 2018
2. Sausville EA, Longo DL. Principles of Cancer Treatment. In: Jameson JL, Fauci AS, Kasper DL, Hauser SL, Longo DL, Loscalzo J, editors. Harrison's Principles of Internal Medicine, 20e. New York, NY: McGraw-Hill Education; 2018

3. Darie $C$, Boutalba $S$, Fichter $P$, Huret JF, Jaillot $P$, Deplus $F$, et al. [Aortitis after G-CSF injections]. Rev Med Interne 2004; 25:225-229.

4. Miller EB, Grosu R, Landau Z. Isolated abdominal aortitis following administration of granulocyte colony stimulating factor (G-CSF). Clin Rheumatol 2016;35:1655-1657.

5. Gornik HL, Creager MA. Aortitis. Circulation 2008;117:30393051.

6. Tso E, Flamm SD, White RD, Schvartzman PR, Mascha E, Hoffman GS. Takayasu arteritis: utility and limitations of magnetic resonance imaging in diagnosis and treatment. Arthritis Rheum 2002;46:1634-1642.

7. Meller J, Strutz F, Siefker U, Scheel A, Sahlmann CO, Lehmann $\mathrm{K}$, et al. Early diagnosis and follow-up of aortitis with [(18)F]FDG PET and MRI. Eur J Nucl Med Mol Imaging 2003:30:730-736.

8. Creager MA, Loscalzo J. Diseases of the Aorta. In: Jameson JL, Fauci AS, Kasper DL, Hauser SL, Longo DL, Loscalzo J, editors. Harrison's Principles of Internal Medicine, 20e. New York, NY: McGraw-Hill Education; 2018

9. Sato $Y$, Kaji S, Ueda H, Tomii K. Thoracic aortitis and aortic dissection following pegfilgrastim administration. Eur J Cardiothorac Surg 2017;52:993-994.

10. Hoshina H, Takei H. Granulocyte-colony stimulating factorassociated aortitis in a woman with advanced breast cancer: a case report and review of the literature. BMC Cancer 2019;19:1217.

11. Mukai T, Kubo S, Morita Y, Yamamoto M, Ikeda M. Aortitis which developed after the administration of granulocytecolony stimulating factor. Mod Rheumatol Case Rep 2020;4:74-78.

12. Parodis I, Dani L, Notarnicola A, Martenhed G, Fernstrom P, Matikas A, et al. G-CSF-induced aortitis: Two cases and review of the literature. Autoimmun Rev 2019;18:615-620. 


\title{
과립구집락자극인자(G-CSF) 유발 대동맥염: 증례보고 및 문헌고찰
}

\author{
이혜원, 하홍일 \\ 한림대학교성심병원 영상의학과
}

\section{초 록}

과립구집락자극인자(G-CSF)는 암환자의 화학요법 치료 중에 발생하는 호중구 감소에 널리 사용된다. 최근 과립구집 락자극인자 유발 대동맥염의 증례들이 보고되고 있다. 본 54세 여자 환자는 유방암으로 보조화학요법치료 중에 호중 구 감소증이 발생하여 과립구집락자극인자를 투여받았다. 환자는 과립구집락자극인자 사용 20일 후에 급성대동맥염 이 발생했으며, 고용량 스테로이드 요법 시행 후 호전되었다. 본 저자들은 영상의학검사를 이용한 진단과 적적한 치 료를 통해 과립구집락자극인자 유발 대동맥염의 성공적 치료를 경험하였기에 문헌 고찰과 함께 보고하는 바이다. 